\title{
O przynależeniu jako naczelnej wartości domu
}

\author{
Patryk Popławski \\ (Uniwersytet Mikołaja Kopernika w Toruniu, \\ Wydział Filozofii i Nauk Społecznych)
}

\section{Wprowadzenie}

Jednym z najstarszych zachowanych dzieł literackich, w których pojawia się motyw tęsknoty za domem, jest grecki epos Homera Odyseja. Główny bohater, Odyseusz, zostaje przeklęty przez Posejdona za zabójstwo cyklopa Polifema: ma już nigdy nie postawić nogi na ziemi ojczystej, a jeżeli dane mu będzie zobaczyć swój $\mathrm{kraj}$, to zastanie go w kłopotach.

Odyseja opisuje tułaczkę dręczonego tęsknotą za domem bohatera. Skąd jednak bierze się ta tęsknota? Co decyduje o tym, że dom jest miejscem, do którego człowiek pragnie wracać? Dlaczego mówi się, że wszędzie jest dobrze, ale w domu najlepiej? Istnieją co do tego różne powody. W domu cenimy sobie na przykład to, że swoją realizację znajdują w nim wartości bezpieczeństwa i prywatności. Inną taką wartością, jak pokażemy w niniejszym artykule, jest „przynależenie". Stawiamy bowiem tezę, że przynależenie jest jedną z nadrzędnych wartości domu. Pokażemy, że pośród tego, co cenimy sobie w domu najbardziej, jest to, że dom daje nam pewne całości - zdefiniowane w dalszej części tekstu - do których chcemy przynależeć.

W celu jasnego wskazania przedmiotu niniejszej pracy musimy zarysować pewne rozróżnienie. Czym innym jest wartość „przynależenia do domu”, a czym innym „przynależenie” jako wartość domu. Gdybyśmy mówili, że ważne jest dla nas przynależenie do domu, przedmiotem artykułu mogłoby być zbadanie 
powodów, dla których jest to dla nas ważne, na przykład powiedzielibyśmy, że cenimy sobie przynależenie do domu, ponieważ spełniają się w nim potrzeby bezpieczeństwa, prywatności i tak dalej. Nie to jednak jest przedmiotem niniejszej pracy. Naszym celem jest pokazanie, że „swoim domem” nazywamy takie miejsca i takie grupy, które realizują różne potrzeby przynależenia, na przykład do fizycznego miejsca lub do rodziny, podobnie jak realizowane są potrzeby bezpieczeństwa i prywatności. Oczywiście prawdą jest, że jeśli cenimy sobie w domu przynależenie do czegoś, to możemy powiedzieć, że jednym z powodów, dla których cenimy sobie przynależenie do domu, jest na przykład to, że dom pozwala nam na realizację cennej dla nas wartości przynależenia do fizycznej przestrzeni i rodziny. Dom traktujemy zatem jako pewną całość, na którą składają się również inne całości umożliwiające przynależenie do nich. I to przynależenie do tych całości będziemy badać ${ }^{1}$

Źródłami dla rozważań aksjologicznych, w celu rozpoznania kontekstu przynależenia jako wartości domu, będą język potoczny oraz badania i namysł prowadzone w ramach psychologii i filozofii. Należy mieć przy tym na uwadze, że w literaturze polskiej i zagranicznej znajdujemy nieliczne prace empiryczne i teoretyczne związane z zagadnieniem domu, nie mówiąc już o pogłębionej analizie związanych z nim wartości. Zadanie, które sobie tutaj stawiamy, jest zatem dodatkowo utrudnione.

Wybór literatury, ze względu na małą objętość artykułu, został zawężony. W wyniku selekcji literatury psychologicznej i filozoficznej dobrano takie pozycje, które są, zdaniem autora niniejszej pracy, najbardziej użyteczne czy też warte uwagi, aby nakreślić wątki poruszane w poszczególnych sekcjach. Autor nie aspiruje do dogłębnego opisania poruszanych tu wątków, ale jedynie do ich wyraźnego zarysowania. Stąd też literatura, która może być użyteczna do bardziej szczegółowych i dogłębnych analiz, została pominięta. Takie badania z pewnością wymagają osobnych prac.

Istnieją oczywiście różne znaczenia wyrażenia „dom”. W najprostszym rozumieniu dom to może być po prostu pewien wydzielony obszar, który - na przykład - na mocy aktu własności należy do jakiejś osoby. Jednakże dom, nawet w fizycznym rozumieniu, ma swoją płaszczyznę społeczną, sprawia, że przynależymy do jakiegoś sąsiedztwa. Cenienie sobie przynależenia do tak rozumianego domu może mieć wiele powodów - po pierwsze to, że czujemy, iż przynależymy do tego fizycznego miejsca; po drugie, dom daje nam prywatność i bezpieczeństwo (w których ujawnia się potrzeba przynależenia), ale jednocześnie tym powodem nie musi być to, że cenimy sobie przynależenie do sąsiedztwa - może być nam ono obojętne. 
Artykuł składa się z pięciu części. W pierwszej: wprowadzimy definicję „przynależenia" i jego potencjalnie aksjologicznego kontekstu. W drugiej: sprawdzimy, co na temat przynależenia i domu ma do powiedzenia psychologia. W trzeciej część pokażemy ujęcie tego zagadnienia ze strony filozoficznej. W czwartej części zbadamy, w jakich kontekstach pojawia się nazwa „dom”, i sprawdzimy, w jakiej relacji pozostaje do wartości przynależenia. W ostatniej części, będącej jednocześnie zakończeniem tej pracy, spróbujemy odpowiedzieć na pytanie, czy przynależenie może zostać uznane za jedną $\mathrm{z}$ wartości nadrzędnych $\mathrm{w}$ domu ${ }^{2}$.

\section{O znaczeniu słowa „przynależenie”}

Wartość, o której będziemy mówić, można scharakteryzować jako cenny dla pewnej osoby stan (w sensie emocjonalnym) odczuwania tego, że jest częścią określonej przez nią całości. Przez „stan” rozumieć będziemy sytuację, w której ktoś się znajduje

2 Bazą wyprowadzenia z języka potocznego definicji „przynależenia” i przeglądu znaczeń „domu” będą wybrane słowniki języka polskiego. Dla różnych części niniejszego artykułu zastosowano odmienne kryteria wyboru słowników. W pierwszej części artykułu kierowano się kryterium, którym jest względna aktualność. Internetowy Słownik Języka Polskiego PWN wydaje się najlepiej zaktualizowanym słownikiem spośród tych, które oddają zwyczajowe znaczenie słów. Sam wybór takiego kryterium jest podyktowany bardzo prostym powodem - w tej części charakteryzujemy przynależenie i chcemy to zrobić, odwołując się do możliwie najprostszej i najpowszechniejszej intuicji językowej. W czwartej części zdecydowano się na kryterium ilościowe, żeby pokazać jak najwięcej znaczeń nazwy „dom”. Przegląd słowników języka polskiego pokazuje bowiem, że różnice, jakie można znaleźć w definiowaniu tego terminu, mają przede wszystkim charakter ilościowy, w bardzo zaś małym stopniu jakościowy. Znaczy to tyle, że pewien słownik A definiuje wyraz „dom” lepiej niż B, ponieważ podaje znaczenia zawarte w B oraz dodaje również nowe, którego w słowniku B nie było. Drogą eliminacji wybrano Słownik Języka Polskiego jako ten, który podaje największą liczbę znaczeń słowa „dom”.

3 Pojawia się tutaj pytanie, czy przynależenie - rozumiane w sensie opisowym, czyli takim, że stwierdzamy, iż x jest w takiej relacji z y-iem, że x jest częścią y-a - to relacja symetryczna. Przy rozumieniu „części” jako obiektu, który daje się wyodrębnić jako samodzielny element całości, relacja ta jest asymetryczna, to znaczy jeżeli x jest częścią $y$-a, to nieprawdą jest, że y jest częścią x-a. Jeżeli, na przykład, cegła jest częścią budynku, nie znaczy to, że budynek jest częścią cegły. Jest to jeden $\mathrm{z}$ podstawowych aksjomatów mereologicznych.

4 Zob. hasło „Stan”, w: Słownik języka polskiego PWN, URL: https://sjp.pwn.pl/sjp/stan;2523760. html. Istnieją inne znaczenia słowa „stan”, jednak tylko jedno z nich interesuje nas w kontekście rozważanego zagadnienia. W szczególności nie chodzi nam tutaj o „czyjeś usposobienie lub nastrój”. 
modzielny element całości ${ }^{5}$, zaś przez „całość” - wszystkie części razem wzięte „Określoność” oznacza, że nigdy nie chodzi o bycie częścią czegokolwiek - zawsze w świadomości podmiotu istnieje jakaś lepiej lub gorzej określona forma tej całości. Kiedy Jan mówi: „w domu cenię sobie najbardziej to, że jestem częścią czegoś większego", to zawsze ma na myśli pewien mniej lub bardziej wyraźny obraz tego, jak ta całość wygląda, na przykład uznaje za ważną sytuację, w której dom daje mu szeroko rozumiane miejsce w rodzinie albo w przestrzeni fizycznej.

Problemem pozostaje nazewnictwo. Poszukiwanie właściwego słowa, aby oddać tę specyficzną wartość, stanowi bowiem nie lada wyzwanie. W języku polskim nie istnieje pojedynczy wyraz, który w pełni reprezentowałby ten stan. Wydaje się jednak, że moglibyśmy rozważyć tutaj trzy rzeczowniki: „należenie”, „przynależność” i „przynależenie”. Spójrzmy zatem na te nazwy i spróbujmy wybrać spośród nich tę, która najlepiej będzie oddawać sens omawianej wartości.

Ze względu na to, że o „byciu częścią jakiejś całości” często się mówi, że ktoś lub coś należy do czegoś, na przykład: „Jan należy do organizacji charytatywnej”, można byłoby rozważyć rzeczownik „należenie”, który pochodzi bezpośrednio od czasownika „należeć”7. Jednakże „należenie”, chociaż faktycznie obejmuje swoim zakresem bycie częścią jakiejś całości ${ }^{8}$, w pewnych kontekstach konotuje z poczuciem bycia czyjąś własnością. Rzeczywiście: „Jan należy do organizacji charytatywnej” - może i nie wywołuje skojarzeń w postaci: „Jan jest własnością organizacji charytatywnej”, ale już w innym kontekście czasownik „należy” może

5 Zob. hasło „Część”, w: Słownik języka polskiego PWN, URL: https://sjp.pwn.pl/sjp/czesc;2450589. html. W tym słowniku w definicji „części” mowa jest o „przedmiocie”. Nie jest jasne, czy chodzi o przedmiot rozumiany wąsko (jako element materialny), czy przedmiot rozumiany szeroko, a więc również abstrakcyjnie. Dlatego też proponujemy, żeby uniknąć niejasności, zastąpić tutaj „przedmiot” określeniem „obiekt”, tzn. jest to dowolny element rzeczywistości, który daje się wyodrębnić jako samodzielny element $\mathrm{z}$ dowolnej całości. Jest to jak najbardziej intuicyjny zabieg - kiedy mówimy, że „x jest częścią jakiejś grupy”, to nie chcemy przecież powiedzieć, że ciała składające się na grupę tworzą jakiś jeden fizyczny obiekt.

6 Zob. hasło „Całość”, w: Słownik języka polskiego PWN, URL: https://sjp.pwn.pl/slowniki/całość. html.

7 Zgodnie $\mathrm{z}$ regułami słowotwórstwa $\mathrm{w}$ języku polskim rzeczowniki odczasownikowe tworzy się zazwyczaj poprzez dodanie przyrostka -nie, -enie, -anie albo -cie. Por. R. Grzegorczykowa, Zarys słowotwórstwa polskiego. Słowotwórstwo opisowe, Państwowe Wydawnictwo Naukowe, Warszawa 1979, s. 31-32.

8 Zob. hasło „Należeć”, w: Słownik języka polskiego PWN, URL: https://sjp.pwn.pl/szukaj/należeć. html. Podano tam różne znaczenia hasła „należeć”: a) być czyjąś własnością, b) być czyimś mężem lub kochankiem, czyjąś żoną lub kochanką, c) wchodzić w skład jakiejś całości, w zakres czegoślub być członkiem czegoś, d) brać w czymś udział, e) stanowić czyjś przywilej, obowiązek lub prawo. 
takie skojarzenia budzić. Osoba, która usłyszy, że czyjąś wartością jest „należenie do kogoś”, niewątpliwie może sobie pomyśleć o jakiejś formie niewolnictwa. Zależy nam tutaj na tym, żeby to słowo kojarzyło się w miarę jednoznacznie, niezależnie od kontekstu, dlatego nazwanie wartości po prostu rzeczownikiem pochodzącym od czasownika „należeć” nie będzie odpowiednie.

„Przynależność” i „przynależenie” to dwa słowa, którym najbliżej jest do oddania stanu bycia częścią jakiejś całości. „Przynależność” oznacza albo bycie częścią jakiejś całości, albo prawnie rozumianą rzecz ruchomą, należącą do właściciela rzeczy głównej, pozostającą z nią w związku i służącą do korzystania z niej'. Drugie znaczenie wyklucza to słowo jako dobrze oddające sens omawianej wartości. Intuicje bowiem, w kontekście rozważania „przynależności” jako wartości, mogą być dwojakie: możemy pomyśleć albo o osobie przynależnej do pewnego obiektu, albo o obiekcie przynależnym do pewnej osoby. Nie jest jasne zatem, co tu byłoby wartością - fakt, że osoba jest do czegoś przynależna, czy raczej to, że coś jest przynależne do tej osoby.

Z kolei ze słowem „przynależeć”, od którego pochodzi rzeczownik „przynależenie", bywały pewne problemy. Chodziło o to, czy należy je uznać za poprawne. Na przykład Nowy/Wielki słownik poprawnej polszczyzny PWN uznaje czasownik "przynależeć" za słowo niepoprawne i przestarzałe, a zatem i za takie słowo należałoby uznać rzeczownik „przynależenie”. Jak jednak zauważa Mirosław Bańko, ten wyraz bardzo często pojawia się w licznych dziełach literackich i nierozsądnie byłoby oskarżać wszystkich tych autorów o błąd - zwłaszcza że autorytet kulturalny ma dla Polaków duże znaczenie ${ }^{10}$. Aktualnie Słownik języka polskiego PWN uznaje to słowo za poprawne i podaje jego definicję. Zgodnie z nią pochodzący od tego czasownika rzeczownik „przynależenie” oznacza (tylko) bycie częścią jakiejś całości ${ }^{11}$. Jak się zatem zdaje, ten wyraz jest najlepszym wyborem, ponieważ ma jedno znaczenie, i to w dodatku takie, które nas tutaj interesuje.

Mając powyższe na uwadze, właśnie takie określenie i jego rozumienie przyjmiemy na oznaczenie omawianej wartości. Musimy jednak dokonać pewnych

9 Zob. hasło „Przynależność”, w: Słownik języka polskiego PWN, URL: https://sjp.pwn.pl/sjp/przynaleznosc;2512324.html.

10 Jest to odpowiedź prof. Bańko na pytanie od jednego z użytkowników słownika. Zob. M. Bańko, przynależeć, „Poradnia Językowa PWN”, URL: https://sjp.pwn.pl/poradnia/haslo/przynalezec;7299.html.

11 Zob. hasło „Przynależeć”, w: Słownik języka polskiego PWN, URL: https://sjp.pwn.pl/szukaj/ przynale\%C5\%BCe\%C4\%87.html. 
regulacji, ponieważ ta definicja, mimo że jest bardzo bliska temu, co próbujemy powiedzieć, nadal nie oddaje w pełni sensu sytuacji mogącej prezentować jakąś wartość. Umówmy się, że „przynależenie”, rozumiane jako wartość, oznaczać będzie dokładnie to, że człowiek jest częścią pewnej określonej całości. Czyli, po pierwsze, chodzi o mniej lub bardziej określoną całość. I, po drugie, częścią nie jest dowolny obiekt, lecz konkretnie człowiek. Powiemy więc, że Jan, który uważa, że najcenniejsze dla niego jest przynależenie, ma na myśli to, że za wartość nadrzędną uznaje bycie częścią pewnej określonej całości, na przykład rodziny, mieszkania, organizacji społecznej, gangu złodziejskiego, mafii, szkoły, uniwersytetu i tak dalej.

Oczywiście wypowiedzenie tej wartości w języku może przybierać różne formy. Mówi się czasami, że najważniejsze w życiu jest posiadanie ${ }^{12}$ przyjaciół. W rzeczywistości jednak chodzi właśnie o bycie częścią jakiejś całości, w tym przypadku o bycie częścią określonej grupy ludzi. To wydaje się jasne. Nic nie stoi również na przeszkodzie, żeby powiedzieć, że „najważniejsze w życiu jest to, żeby do kogoś należeć”. Żeby jednak zidentyfikować taką wypowiedź jako wyraz omawianej wartości, potrzebny jest kontekst, ponieważ nie wiemy, czy chodzi o to, że ta osoba ceni sobie niewolnictwo, czy może chce być częścią pewnej całości, którą jest, powiedzmy, małżeństwo. Stąd właśnie wybraliśmy „przynależenie”. Jak się zdaje, jest ono najmniej rozmytym znaczeniowo określeniem i nie wywołuje skojarzeń, które nie mają związku z badanym przez nas stanem. Dokonaliśmy też pewnych regulacji. A zatem od teraz, gdy mówimy o rozważanej w tej pracy wartości, celowo unikamy nieintuicyjnych wyrażeń, takich jak „należenie”, i ściśle trzymamy się nazwy „przynależenie”.

\section{Dom i przynależenie w literaturze psychologicznej}

Literatura psychologiczna pokazuje pewne przejawy zainteresowania zagadnieniem domu, chociaż nie można powiedzieć, że są to jakieś szeroko zakrojone badania. Wśród tych nielicznych prac znajdujemy na przykład design psychology ${ }^{13}$. To nurt zajmujący się kreowaniem wnętrz, które mają mieć dla nas jakieś zna-

\footnotetext{
12 Oczywiście nie „posiadanie” w sensie ścisłym, bo przyjaciół jak przedmiotów raczej „posiąść” nie można.

13 Określenie wprowadzone przez Toby Israel, prekursorkę design psychology.
} 
czenie. Psycholożka Toby Israel, twórczyni tej idei, twierdzi, że ludzie, poszukując mieszkań i projektując domy, dążą do odtworzenia warunków, w których czuli się dobrze i bezpiecznie. W swojej pracy przedstawia „udomowioną” wersję piramidy Maslowa, gdzie kolejno - począwszy od szczytu piramidy - wskazuje potrzeby, które mają znaleźć swoje spełnienie w domu. A więc mamy: a) miejsce jako samorealizację, b) satysfakcję z potrzeby estetycznej, c) satysfakcję z potrzeby społecznej, d) satysfakcję z potrzeby psychologicznej i e) schronienie ${ }^{14}$.

Israel korzysta tutaj z klasycznego modelu potrzeb człowieka, na podstawie których moglibyśmy wyprowadzić pewne wartości. Maslow podjął się takiej próby i konkretnie $z$ potrzebą samorealizacji powiązał takie wartości jak prawda, dobro, piękno, perfekcja, doskonałość i elegancja. To one, jego zdaniem, właśnie motywują człowieka do spełniania potrzeby samorealizacji ${ }^{15}$.

Możemy jednak pójść krok dalej i szukać kolejnych wartości w każdym stopniu piramidy, na przykład dla potrzeb fizjologicznych wartościami mogłyby być sytość, bezpieczeństwo i tym podobne. Wolno więc powiedzieć, że pewne wartości wiążą się z poszczególnymi potrzebami również w przypadku domu - ze schronieniem wiąże się wartość życia, z satysfakcją z potrzeby psychologicznej wiąże się prywatność, z satysfakcją z potrzeby estetycznej prestiż (ładne mieszkanie), a z miejscem jako samorealizacją po prostu samorealizacja jako swoista wartość, która znajduje swoje spełnienie właśnie w domu.

Przynależenie można byłoby, po pierwsze, rozpoznać zarówno w potrzebie schronienia, jak i w potrzebach społecznych. W tym pierwszym rozumieniu „przynależenie” to bycie częścią jakiegoś fizycznego miejsca, które - wraz z nagromadzonymi w nim przedmiotami - zapewnia nam schronienie. Dom składa się jednak nie tylko z dachu, okien, cegieł, drzwi, łóżka, ale też - a może przede wszystkim - właśnie z osób, które ten dom zamieszkują, a które nie są tylko zwykłymi ciałami, lecz są bytami, w których rozpoznajemy podmioty o rozumnej naturze.

Przynależenie ma zatem dwie płaszczyzny: a) fizyczną, to znaczy chodzimy po tym domu, śpimy w swoim łóżku, oglądamy telewizję na kanapie, ogólnie rzecz biorąc - dysponujemy swobodnie przestrzenią, a także b) społeczną, to znaczy łączą nas jakieś mniej lub bardziej zażyłe relacje z osobami, które również przy-

14 T. Israel, Some Place Like Home: Using Design Psychology to Create Ideal Places, Wiley, Hoboken, N.J. 2003, s. 56.

15 A. Maslow, The farther reaches of human nature, Viking Press, New York 1971, s. 105-149. 
należą do tego fizycznego miejsca. To z tymi ludźmi dzielimy doświadczenia, historię, nazwisko i rytuały życia codziennego. To oni realizują naszą potrzebę bycia akceptowanymi i kochanymi.

Do potrzeb społecznych należy również potrzeba ofiarności. Bywa bowiem tak, że matka chce opiekować się dziećmi, wychowywać je, ojciec chce zapewnić byt swojej rodzinie, a członkowie mafii chcą dbać o kolegów i dobrą reputację, poświęcając przy tym coś ważnego, jak na przykład wolny czas, prywatność, bezpieczeństwo i tak dalej. Chcemy mieć jakieś znaczenie dla tej grupy. W tej potrzebie ofiarności ujawnia się potrzeba przynależenia.

Po drugie, potrzebą, w której zawiera się potrzeba przynależenia, jest pragnienie rozwoju czegoś, czego jest się częścią, do czego się przynależy. Dom daje taką możliwość, bowiem możemy go kształtować. Możemy na przykład mieć wpływ na rozwój ojczyzny, która jest naszym ukochanym domem. Czynny udział w życiu politycznym i społecznym, poczucie, że mamy wpływ na jego kształtowanie się, realizuje potrzebę przynależenia do czegoś, co za naszym wpływem rozwija się i zmienia. Innym przykładem może być chęć budowania (w sensie fizycznym) czegoś, do czego przynależymy, zmieniania struktury i wyglądu. Wolno nam więc powiedzieć, że i w potrzebie samorealizacji, i w potrzebie satysfakcji estetycznej w domu przejawia się potrzeba przynależenia, jeśli samorealizujemy się czy też czerpiemy satysfakcję estetyczną, rozwijając nasz dom.

Lepszą jednak podstawą na gruncie psychologii mogą być badania empiryczne, dzięki którym uda się ustalić listę cenionych przez ludzi wartości dotyczących domu. W 1986 roku Judith Sixsmith opublikowała eksperyment, którego jednym z głównych celów było wyodrębnienie znaczeń domu ${ }^{16}$. Do jego przeprowadzenia wykorzystano metodę MST Q Stevensona i procedurę „własnych kategorii”. Pierwsza polega na tym, że uczestnicy przyporządkowują obiekty sortowane do różnych kategorii według ustalonego kryterium. Druga zaś na tym, że te kategorie wymyślają wcześniej sami badani ${ }^{17}$. Przebieg eksperymentu wyglądał w następujący sposób:

1. Uczestnicy, którymi byli studenci, utworzyli opisy wszystkich przeszłych, teraźniejszych i możliwych idealnych domów, które przychodzą im do głowy. Poza tym mieli wskazać miejsca, których nigdy nie nazwaliby domem.

\footnotetext{
16 J. Sixsmith, The meaning of home: an exploratory study of environmental experience, „Journal of Environmental Psychology" 1986, Vol. 6, No. 4, s. 281-282.

17 Tamże, s. 283.
} 
2. Drugim krokiem było utworzenie przez respondentów kategorii, według których mogliby posortować domy.

3. Trzecim krokiem było sortowanie tych domów według prostego kryterium: „co jest dla mnie domem”.

W rezultacie udało się wyodrębnić szereg typów domu. Wskazywano między innymi miasto (town), dom posiadany na własność (owned home), pokój (room), mieszkanie przyjaciół (friends house), ojczyznę (homeland) czy dom z dzieciństwa (childhood house) ${ }^{18}$. To, co jednak ciekawsze, pojawia się w dalszej części pracy. Chodzi tutaj o kategorie znaczeniowe, do których respondenci przyporządkowywali te domy według ustalonego kryterium. W nawiasach podano częstotliwość, z jaką dopasowywano do nich typy. Kategorie te możemy uporządkować od najczęściej do najrzadziej wskazywanych ${ }^{19}$.

1. Przynależenie

2. Szczęście, zakres usług, wyrażanie siebie

3. Przestrzenność

4. Rodzaj relacji międzyludzkich

$(\mathrm{f}=10)$

5. Perspektywa czasowa

6. Stałość

7. Odpowiedzialność

8. Struktury fizyczne; przyjaciele i rozrywka

9. Styl architektury

10. Środowisko pracy, środowisko emocjonalne, jakość relacji międzyludzkich, preferencja wracania, znaczące miejsca, prywatność $\quad(\mathrm{f}=4)$

11. Wiedza

12. Krytyczne doświadczenia.

Zważywszy na małe wymiary niniejszej tekstu, nie będziemy się przyglądać wszystkim kategoriom - w artykule Sixsmith znajduje się w omówienie każdej z nich. Skupimy się tutaj na najczęściej wskazywanej - czyli na przynależeniu. Musimy jednak nadmienić, że w niektórych innych kategoriach także ujawnia się kategoria przynależenia. Stałość wyraża pewne formy przynależenia, na przykład do miejsca fizycznego, a szczęście może być kojarzone z domem, ponieważ

18 Tamże, s. 286.

19 Tamże, s. 287. Kategorie w oryginalnym brzmieniu są następujące: (1) belonging, (2) happines, extent of services, self-expression, (3) spatiality, (4) type of relationship, (5) time perspective, (6) permanence, (7) responsibility, (8) psychical structures, friends and entertainment, (9) architectual style, (10) work environment, emotional environment, quality of relationships, preference to return, meaningful places, privacy, (11) knowledge, (12) critical experience. 
właśnie tym, co nas uszczęśliwia, mogłoby być przynależenie. Czuć się częścią pewnej całości możemy też ze względu na to, że całość daje nam więzi emocjonalne albo wiążą się z nią pewne doświadczenia. Istotne jest to, że miejsca, w których dorastaliśmy, zdobywaliśmy przyjaźnie i pierwszą miłość, mogą kojarzyć się z przynależeniem, ale nie muszą. Jak się zdaje, jeżeli przeważają u nas negatywne skojarzenia związane z danym miejscem czy grupą, to może być tak, że nie czujemy się częścią tej całości, nawet jeśli pojawiają się też pozytywne skojarzenia.

Chociaż w powyższym badaniu nie chodziło o wskazanie wartości domu, jest ono dla nas ważne, ponieważ informuje nas o skojarzeniu poczucia bycia częścią jakiejś całości z domem. Jeżeli tak bardzo kojarzymy przynależenie $\mathrm{z}$ domem, to przyczyną tego może być fakt, że traktujemy przynależenie jako wartość nadrzędną domu. Autorka pisze o tej kategorii: komfort, wypoczynek i znajomość otoczenia przyczyniają się do poczucia przynależenia do domu. Odsyła tutaj do pracy Yi-Fu Tuana ${ }^{20}$.

Zdaniem tego autora doświadczenie jest podstawowym sposobem, w jaki człowiek poznaje świat. Doświadczać możemy na dwa sposoby: pasywnie lub aktywnie. Dotyk, zapach i smak to doświadczenia pasywne, prowokowane przez zewnętrzne bodźce, natomiast słuchem i wzrokiem poznajemy świat aktywnie. Miejsca są centrami znaczeń konstruowanymi zarówno przez doświadczenia pasywne, jak i aktywne - te ostatnie prowadzą do ich obiektywizacji. Ponadto większość miejsc nie ma nazw, a zatem znajduje się w naszej podświadomości. Dać miejscu nazwę, to znaczy rozpoznać je świadomie. Dom jest takim zwerbalizowanym centrum znaczeń ${ }^{21}$.

Znać miejsce w pełni, to znaczy zarówno rozumieć je w abstrakcyjny sposób, jak i znać je tak, jak jedna osoba zna drugą. O domu Tuan pisze, że pierwotnym jego znaczeniem jest schronienie. To jedyne miejsce, gdzie możemy otwarcie i w pełni komfortowo przyznać się do naszych słabości i potrzeb fizycznych. Tam jemy, myjemy się, odpoczywamy i wracamy, gdy jesteśmy zmęczeni lub chorzy, albo wtedy, gdy nie możemy już dłużej zachować odwagi w obliczu świata. Dom jest częścią naszej rutyny, wychodzimy do rozmaitych miejsc, ale wracamy tylko do jednego - do domu ${ }^{22}$.

20 Tamże, s. 287.

21 Yi-Fu Tuan, Place: An Experimental Perspective, „Geographical Review” 1975, Vol. 65, No. 2, s. $151-153$.

22 Tamże. 
Sixsmith, jak się zdaje, trafnie rozpoznała, że znajomość miejsca związana jest z poczuciem przynależenia. Czymże innym jest opis domu Tuana, jeśli nie właśnie charakterystyką miejsca, $\mathrm{z}$ którym rzeczywiście wiąże nas poczucie przynależenia? Elementy opisujące pewien rodzaj swobody domowej wydają się stanowić jego podstawę. Płaszczyzna społeczna, o której mówiliśmy przy piramidzie Maslowa, również ma tutaj znaczenie. Dom, do którego przynależymy, to takie miejsce, w którym są przedmioty i ludzie, z którymi to razem tworzymy pewną całość.

Taką znajomość czegoś, która przyczynia się do poczucia przynależenia i niewątpliwie ma związek z pewną swobodą, można określić mianem swojskości. Swobodnie poruszamy się w miejscu znanym, w którym wszystko, włącznie z nami, ma swoje miejsce. Taką „swojskość” przeciwstawiamy „obcości”, jako czemuś, co sprawia, że czujemy się nieswojo - czemuś, do czego nie przynależymy i czego nie znamy.

Dlaczego najlepszym przyjaciołom mówimy, żeby czuli się u nas jak w domu? Prawdopodobnie właśnie dlatego, że chcemy, aby wiedzieli, że są częścią tego miejsca, tego wszystkiego, co ten dom tworzy ${ }^{23}$. Pozwalamy im zatem swobodnie robić sobie herbatę, otwierać lodówkę czy leżeć na kanapie, ponieważ skoro przynależenie jest cenne dla nas, to zakładamy, że jest też cenne dla naszych gości.

Czasami też mówimy, że nie czujemy się gdzieś jak w domu. Na przykład przeprowadzka do nowego miasta czy porzucenie domu rodzinnego na rzecz samodzielnego życia budzą w nas uczucie obcości. Wtedy próbujemy przełamać to uczucie i wprowadzić odrobinę swojskości, żeby zrealizować cenny dla nas stan przynależenia gdzieś. Gromadzimy więc znane nam rzeczy, rozstawiamy fotografie rodzinne, owijamy się ulubionym kocem od babci, wkładamy nasze ubrania do szafy w nowym miejscu. Próbujemy stworzyć przestrzeń, w której moglibyśmy poczuć się jak w domu, to znaczy tak, jakbyśmy byli „w naszym miejscu”. Widzimy więc, że swojskość wiąże się z poczuciem przynależenia, zaś obcość z poczuciem, że nie przynależymy do pewnego miejsca.

Innym podobnym przykładem są podróże, wtedy bardzo często tęsknimy za domem, jak Odyseusz w czasie swojej tułaczki. Istnieje coś niezwykle podniecającego w myśli o powrocie do swojego domu. Odpoczynek i spokój znajdujemy nie byle gdzie, lecz właśnie tam, gdzie czujemy się u siebie, tam gdzie przynależymy.

23 Oczywiście przy założeniu, że są to szczere słowa, a nie wypowiedziane z grzeczności. 
Zauważmy dodatkowo, że możemy mówić o różnych stopniach przynależenia, a więc rozmaitych typach domów. Kiedy mówimy o ukochanym domu rodzinnym i ojczyznę nazywamy swoim domem, w obu przypadkach mamy na myśli przynależenie, jednak nasze odczucie tego przynależenia jest mniej lub bardziej intensywne. Jednym z głównych czynników decydujących o tym, jak bardzo czujemy, że przynależymy, jest właśnie znajomość miejsca. Na przykład z racji tego, że dom rodzinny wydaje się nam bardziej swój, możemy czuć, że przynależymy do niego bardziej niż do miasta rodzinnego czy swojego kraju.

\section{Dom i przynależenie w literaturze filozoficznej}

Jeśli chodzi o filozoficzną refleksję nad wartością przynależenia, warte uwagi są pisma Martina Heideggera, Hannah Arendt oraz praca zbiorowa Ulricha Schrade'a, Bogusława Wolniewicza i Jana Zubelewicza. Autorzy tych prac w pewien sposób dotykają zagadnienia przynależenia i domu.

W Budować, mieszkać, myśleć Heidegger szuka odpowiedzi na dwa pytania: (1) czym jest zamieszkiwanie i (2) w jakiej mierze budowanie przynależy do zamieszkiwania ${ }^{24}$. Na początku zauważa, że obszary, które zamieszkujemy, nie ograniczają się do mieszkań rozumianych jako budowle. Jako przykład podaje kierowcę ciężarówki, który jest „u siebie w domu”, gdy znajduje się podczas jazdy na autostradzie. Heidegger rezygnuje $\mathrm{z}$ „domu” czy „mieszkania” wąsko pojmowanego jako jakiś budynek. W ten sposób tworzy podstawę do powiązania „zamieszkiwania” z „byciem”25.

Jest bowiem tak, że pierwotne znaczenie „budowania”, mówi Heidegger, to „zamieszkiwanie”. Budowanie jest już zatem zamieszkiwaniem. Z kolei „zamieszkiwać” to „pozostawać, przebywać". Człowiek zatem „jest”, o ile buduje czy też zamieszkuje ${ }^{26}$. Zamieszkiwanie w ten sposób staje się warunkiem „bycia” człowieka. W jaki jednak sposób się ono realizuje? Odpowiedź na to pytanie jest złożona.

Po pierwsze, przez pobyt na Ziemi, pod Niebem, w obliczu Istot Boskich i wespół ze śmiertelnymi. Ludzie uwikłani są zatem w czworokąt, którego elementy

24 M. Heidegger, Budować, mieszkać, myśleć, tłum. K. Michalski, „Teksty: teoria literatury, krytyka, interpretacja" 1974, $\mathrm{nr}$ 6(18), s. 137.

25 Tamże, s. 138.

26 Tamże, s. 139. 
to warunki powiązane $\mathrm{z}$ istnieniem człowieka. Heidegger charakteryzuje je następująco:

(1) Śmiertelni mieszkają o tyle, o ile wyzwalają swoją istotę na Ziemi.

(2) Śmiertelni mieszkają o tyle, o ile godzą się na Niebo jako Niebo, czyli na pozostawienie zjawisk przyrodniczych ich naturalnemu biegowi.

(3) Śmiertelni mieszkają o tyle, o ile oczekują Istot Boskich jako Boskich. (Ludzie nie czynią się bogami i nie służą bożyszczom, a także godzą się na wszystko, co jest zgodne z zamysłem Istot Boskich).

(4) Śmiertelni mieszkają, o ile posłuszni są własnej istocie, czyli godzą się na swoją śmiertelność i potrafią umierać dobrą śmiercią, pozbawioną uczucia nicości i rozpaczy.

Zamieszkiwać, to zachowywać ten czworoką ${ }^{27}$.

Po drugie, zamieszkiwanie nie wiąże się jedynie tylko $\mathrm{z}$ zachowywaniem czworokąta, lecz także z miejscem w przestrzeni, które przeznaczone jest do tego, żeby człowiek je zamieszkiwał. Istotą zamieszkiwania jest zatem istnienie człowieka w przestrzeni w relacji do określonych miejsc i rzeczy, bowiem to właśnie rzeczy budujemy i zamieszkujemy. Ten pobyt przy rzeczach nie jest jednak dołączony jako „piąty warunek”, lecz raczej jest sposobem, w jaki zachowywany jest ten czworokąt ${ }^{28}$.

Najważniejsza uwaga dla nas pojawia się jednak w późniejszej części pracy. Heidegger pisze, że człowiek i przestrzeń nie stoją do siebie w opozycji. Nie można myśleć o człowieku i o przestrzeni jako czymś osobnym. Kiedy mówimy „człowiek”, to mamy na myśli już zamieszkiwanie, czyli bycie w czworokącie przy rzeczach. Tego przynależenia do czworokąta nie tracimy nawet wtedy, gdy zwrócimy się ku samym sobie. Odchodzimy w ten sposób od rzeczy, ale nie porzucamy pobytu przy nich - dalej bowiem przynależymy do czworokąta i pozostajemy w relacji do rzeczy, które zamieszkujemy ${ }^{29}$. Wiedzieć, gdzie przynależymy, w języku Heideggera oznaczałoby właśnie być świadomym tych czterech warunków. Przynależymy zatem „pod Niebem”, „na Ziemi”, „przy Istotach Boskich” i „wespół z innymi Śmiertelnymi”. To przynależenie realizuje się poprzez budowanie rzeczy.

\footnotetext{
27 Tamże, s. 140-143.

28 Tamże, s. 143.

29 Tamże, s. 147-148.
} 
Czy te rozważania Heideggera mają jakiś wkład w nasze badania nad przynależeniem jako wartością? Co prawda Heidegger nie zajmuje się tutaj wprost wartościami, ale zwraca uwagę na coś ważnego, gdy mówi, że nie możemy utracić przynależenia. Powstaje tutaj bowiem istotne pytanie: jeżeli nie możemy tego utracić, to jak to może być dla nas cenne? W ostatecznym rozrachunku - abstrahując już nawet od koncepcji Heideggera - przecież zawsze jesteśmy częścią czegoś większego, jakiejś całości.

Żeby uniknąć tej niejasności, należy odróżnić „przynależenie” rozumiane jako wartość od „przynależenia” rozumianego jako stwierdzenie faktu. Przypomnijmy, że scharakteryzowaliśmy wartość przynależenia jako cenny dla pewnej osoby stan bycia przez nią częścią określonej całości. W tej wartości nie chodzi zatem o to, żeby zaistniał po prostu fakt, że gdzieś przynależymy. Rzeczywiście, być może zawsze gdzieś przynależymy, ale cenny może być dla nas tylko taki stan przynależenia, który rozpoznajemy i w jakiś sposób go określamy, na przykład „przynależenie do rodziny”, „przynależenie do domu”, „przynależenie do ojczyzny”, ,przynależenie do gangu”, ,,przynależenie do szkoły”. Tu nigdy nie chodzi o przynależenie gdziekolwiek, ponieważ to już jest stan, który nieustannie się realizuje i którego nie możemy utracić, a zatem nie może być cenny. Kiedy piszemy o wartości, mamy na myśli, że przynależenie jest zawsze określone w odniesieniu do czegoś. Kiedy mówimy, że chcielibyśmy gdzieś przynależeć, to w naszej wyobraźni zawsze jawi się jakiś mniej lub bardziej ostry obraz tego, jak to "gdzieś” miałoby wyglądać, mamy pewne wyobrażenie tego, jakie to miałoby być uczucie i co miałoby nam dawać to uczucie. Towarzyszą mu zawsze jakieś emocje, doświadczenia i wyobrażenia. $Z$ faktu, że zawsze gdzieś przynależymy, nie możemy wywnioskować, że mamy poczucie przynależenia, że jest ono dla nas cenne. To my decydujemy o tym, czy przynależenie do pewnej grupy albo miejsca - rozumiane jako stan rzeczy - jest dla nas ważne.

Wątek przynależenia pojawia się również u Arendt. W Kondycji ludzkiej, w kontekście rozważań dotyczących sfery prywatnej i publicznej, autorka pisze, że w myśli greckiej ludzka zdolność do organizacji politycznej, czyli życia publicznego, jest zupełnie odmienna od naturalnego centrum, które stanowi dom. I mimo tego, że powstanie polis i dziedziny publicznej dokonało się kosztem prywatnej sfery rodziny i gospodarstwa domowego, nigdy nie zatracono świętości ogniska domowego. Działo się tak nie ze względu na jakieś poszanowanie własności prywatnej, lecz ze względu na to, że bez domu człowiek nie mógł uczestni- 
czyć w sprawach świata, ponieważ nie miał w nim własnego miejsca, a zatem jakbyśmy to określili terminologią przyjętą w tej pracy - nigdzie nie przynależał. Arendt pisze, że to, iż dom sprawia, że gdzieś przynależymy, jest - jak się zdaje - powodem, dla którego dom występuje jako obiekt pod szczególną ochroną. Jak zauważa, nawet Platon, który chciał zniesienia własności prywatnej i rozszerzenia sfery publicznej, granice między posiadłościami nazywał boskimi ${ }^{30}$.

Zauważmy bowiem, że ognisko domowe daje nam poczucie stabilizacji w życiu codziennym. Tuan, którego myśl wcześniej przytoczyliśmy, pisał, że dom daje nam spokój w chaosie. Dom jest punktem startowym, z którego wychodzimy do świata, żeby mierzyć się z jego wyzwaniami. Przynależymy do różnych miejsc, wiele $z$ nich może nawet nazywamy domem, ale od „swojego domu” oczekujemy, że w nim będziemy przynależeć najbardziej. Utrata czterech kątów jest jednym z najbardziej obciążających psychicznie zdarzeń, które mogą spotkać człowieka - zwłaszcza jeżeli na przykład w wyniku ubóstwa nie możemy znaleźć nowego miejsca, żeby odtworzyć dom. W efekcie pojawia się uczucie, że nigdzie nie przynależymy, że utraciliśmy coś cennego. Nie chodzi tu tylko o fizyczne miejsce, ale też o wszystkie wspomnienia i emocje, które się z nim wiążą. Tracimy więc coś, w czym funkcjonowały całości, których byliśmy częścią, to znaczy rodzinę, miejsce fizyczne i wszystko to, co ten dom tworzyło. Sama myśl o tym powoduje niepokój, więc chronimy nasz dom za wszelką cenę.

Arendt zwraca uwagę na jeszcze jedną rzecz, która jest dla nas istotna. Pisze, że silna granica między dziedziną publiczną i prywatną się zatarła. W dodatku pojawiła się specyficzna dziedzina społeczna, która nie jest ani prywatna, ani publiczna. Domeną polityki niegdyś było „ujawnianie się”, domeną domu zaś „skrytość” czy też po prostu „prywatność”. Dom nie był wtedy miejscem wolności i samorealizacji, lecz konieczności. Wolność przejawiła się na forum politycznym w ramach demokratycznego ustroju. Dzisiaj, jak się zdaje, właśnie dom kojarzy się z miejscem, w którym realizowana jest wolnośćc ${ }^{31}$.

Możemy jednak pójść krok dalej niż Arendt. Zauważmy, że pozycję utraciła dzisiaj również wartość prywatności. Przypuszczalnie zakres tego, co uważano niegdyś za prywatne, wskutek rozwoju mediów i telekomunikacji uległ zmniejszeniu. Pewne zachowania, które niegdyś uważano za niestosowne w sferze publicznej, zaś właściwe w sferze prywatnej, dzisiaj stanowią normalne zjawisko

30 H. Arendt, Kondycja ludzka, tłum. A. Łagodzka, Fundacja Aletheia, Warszawa 2000, s. 33-44.

31 Tamże, s. 33-44. 
w przestrzeni publicznej. Można domniemać, że zmniejszył się zakres tego, co prywatne, a - co za tym idzie - mniej ważna stała się prywatność w domu. Pewną wskazówką, że tak może być, są badania Sixsmith, o których wspominaliśmy wcześniej. Frekwencja wskazań „prywatności” jako ważnego elementu domu jest bardzo niska w stosunku do wskazań innych kategorii znaczeniowych. Ten wątek jednak, podobnie jak wątek wolności, wymaga osobnego zbadania.

Wspominamy tutaj o tym, żeby zaobserwować pewne interesujące zjawisko. Mimo że różne wartości stawały się w obrębie domu mniej lub bardziej cenne na przestrzeni czasu, przynależenie jest pewną stałą wartością, która nie zmieniła swojej pozycji. Dom nadal jest czymś, od czego oczekujemy, żeby przede wszystkim dawało nam miejsce w świecie. Chronimy więc swój dom, ponieważ bez niego staniemy się pozbawieni miejsca, on nas zakotwicza w chaosie tego świata.

Kolejny ważny wkład filozoficzny w rozważania nad domem mają Wolniewicz, Zubelewicz i Schrade, dla których dom jest tworem duchowym, nadbudowanym nad warstwą fizyczną. Dlatego też warstwę fizyczną, w celu odróżnienia jej od warstwy duchowej, określają mianem „mieszkania” i definiują jako twór przestrzenny, wydzielone terytorium, na którym, podlegli ustanowionym przez nas normom, jesteśmy „u siebie”. Z łatwością obserwujemy, że przy takiej definicji mieszkania realizuje się to, co wcześniej określiliśmy mianem „przynależenia” rozumianego jako „bycie częścią jakiegoś fizycznego miejsca” ${ }^{32}$.

Zwróćmy jednak uwagę na tezę autorów dotyczącą warstwy duchowej. Piszą bowiem, że dom jest czymś, w czym człowiek jest ceniony jako wartość samoistna i niewymienna. Dom jest duchową podporą, która sprawia, że mamy poczucie, że ktoś gdzieś jest do nas przywiązany bezwzględnie i bezwarunkowo, jak w wyidealizowanym obrazie matki przywiązanej do swoich dzieci. To daje nam poczucie, że naprawdę musimy być coś warci ${ }^{33}$.

Ta teza jest dla nas szczególnie ważna, ponieważ autorzy zwracają uwagę na istotny aspekt płaszczyzny przynależenia, którą wcześniej określiliśmy mianem „społecznej”. Powiedzieliśmy, że przynależenie może realizować się w różnym stopniu - zarówno w aspekcie „bycia częścią pewnego obiektu fizycznego”, jak i „bycia częścią jakiejś grupy”. Jak się zdaje, kiedy marzymy o mieszkaniu wraz $\mathrm{z}$ jego duchową nadbudową (a więc kiedy marzymy o domu), nie chodzi nam po

\footnotetext{
32 U. Schrade, B. Wolniewicz, J. Zubelewicz, Dom jako wartość duchowa, „Znak” 1996, nr 4(491), s. 90-91.

33 Tamże, s. 95.
} 
prostu o miejsce, do którego będziemy przynależeć, lecz raczej o takie miejsce, do którego będziemy przynależeć najbardziej. Oczekujemy, że realizacja wartości przynależenia w naszym domu obejmie zarówno płaszczyznę społeczną, jak i fizyczną (mieszkanie), nad którą ta społeczna jest nadbudowana, i to w najlepszy możliwy sposób.

Na płaszczyźnie społecznej to bezwarunkowe przywiązanie innych osób do nas, o którym piszą autorzy, zdaje się być kluczowym elementem znajdującym się w wyobrażeniu idealnego domu. Zauważmy, że miejsce, w którym inni ludzie są przywiązani do nas bezwarunkowo, wydaje nam się najbardziej „nasze” i sprawia, iż czujemy, że przynależenie może w nim realizować się najlepiej.

I od domu, jak się zdaje, tego właśnie oczekujemy - chcemy, aby wartość przynależenia realizowała się w nim lepiej niż w innych okolicznościach. Do różnych miejsc możemy przynależeć w różnym stopniu, ale od swojego domu oczekujemy, że w nim będziemy przynależeć najbardziej. A zatem w wyidealizowanym obrazie domu - na płaszczyźnie społecznej - przynależymy bezwarunkowo, to znaczy nasze przynależenie jest tak silne, że czujemy, iż członkowie tego domu będą do nas przywiązani niezależnie od tego, jakimi ludźmi będziemy. Dom daje nam miejsce (w sensie fizycznym i społecznym), do którego chcemy wrócić nawet wtedy, gdy cały świat sprzymierzy się przeciwko nam i już nigdzie indziej nie będziemy mieć „swojego miejsca”.

Na płaszczyźnie fizycznej oczekiwanie najwyższego poziomu realizacji przynależenia może dotyczyć wielu rzeczy. Na przykład tego, że nikt bez naszej zgody nie naruszy granic naszej przestrzeni, że nikt nas z tego mieszkania nie wyrzuci, że będzie ono całkowicie naszą własnością. Tutaj również, jak się zdaje, chcemy, żeby to przynależenie było bezwarunkowe.

\section{„Dom” w pragmatyce językowej}

Dotychczas przyjrzeliśmy się temu, co filozofia i psychologia mają do powiedzenia w temacie przynależenia i domu. Nie zajmowaliśmy się jednak jeszcze zwyczajnym użyciem słowa „dom” w rozmaitych wypowiedziach języka naturalnego, nie podaliśmy też żadnej definicji domu, to znaczy bazowaliśmy na pewnych intuicjach. Warto zbadać, co rozumiemy przez słowo „dom”, gdy używamy tego 
pojęcia $\mathrm{w}$ różnych kontekstach, i czy dowiemy się z tego czegoś na temat kojarzenia wartości przynależenia $\mathrm{z}$ domem.

Słownik Języka Polskiego ${ }^{34}$ proponuje siedem różnych znaczeń nazwy „dom": (1) budynek przeznaczony na mieszkanie, pomieszczenie instytucji, itp.; (2) mieszkanie, pomieszczenie mieszkalne, miejsce stałego zamieszkania, własny kąt; (3) rodzina, domownicy, gniazdo rodzinne, mieszkanie wraz z jego mieszkańcami; (4) ogół spraw rodzinnych, domowych, gospodarstwo domowe; (5) ród, rodzina, dynastia; (6) instytucja państwowa, społeczna, handlowa itp., mieszcząca się zwykle w oddzielnym lokalu lub domu, budynek, w którym się znajduje, zakład, przedsiębiorstwo; (7) miejsce, skąd rozpoczyna się niektóre gry.

Nie stwierdzamy tutaj, że ta lista jest wyczerpująca. Z łatwością można podać jeszcze inne znaczenia, na przykład domem dla leśniczego może być las, a dla jakiegoś podróżnika pewne miasto, które nie jest jego miejscem stałego zamieszkania (na przykład dla Polaka, który odwiedza często Madryt, stolica Hiszpanii może być „drugim domem”). Ta wielość znaczeń otwiera jednak pewien interesujący obszar badawczy, który z pewnością nie zostanie zamknięty w niniejszej pracy. Porzućmy na chwilę rozumienie "przynależenia” jako pożądanego, cennego stanu, i zwróćmy naszą uwagę na „przynależenie” rozumiane deskryptywnie, jako opis stanu rzeczy. W tym rozumieniu przynależenie nie jest wartością, lecz stwierdzaniem pewnego faktu, że $x$ przynależy do $y$, tak jak to wspominaliśmy przy wątkach związanych z pracą Heideggera. Zrezygnujmy też na chwilę z restrykcji, którą nałożyliśmy na definicję przynależenia, że w miejsce $x$ wstawić można tylko podmiot. A zatem przyjmijmy na poczet tej części pracy, że „przynależenie" rozumiane deskryptywnie to po prostu stwierdzenie faktu, że $x$ jest częścia jakiejś określonej całości y. W ten sposób możemy zbadać, czy przy użyciu słowa „dom” pojawiają się intuicje związane z „byciem częścią jakiejś określonej całości”, a potem zastanowimy się, czy może mieć to związek z przynależeniem rozumianym jako wartość. Zrobimy więc coś podobnego do tego, co zrobiła Sixsmith we wcześniejszej sekcji, tyle że zamiast badania skojarzeń znaczeniowych respondentów, zwyczajnie przyjrzymy się temu, jak to słowo jest używane w życiu codziennym.

Zauważmy, w jakich kontekstach używamy nazwy „dom”. Mówimy nie tylko o własnych domach, lecz także cudzych, a nawet o domach towarowych. Często

34 Zob. hasło „Dom”, w: Słownik Języka Polskiego, red. W. Doroszewski, Wydawnictwo Naukowe PWN, Warszawa 1966, s. 233-236. 
posługujemy się czasownikami „udomawiać kogos” albo „zadomawiać się”. Język stanowi bogatą skarbnicę przykładów, które - zdaniem autora niniejszej pracy - sugerują, że gdzieś za nazwą „dom” głęboko w jej znaczeniu kryje się właśnie przynależenie. Zastanówmy się nad różnymi kontekstami, w których używa się tego słowa.

Weźmy na przykład wspomniany dom towarowy - jest on niewątpliwie miejscem, do którego przynależą pewne obiekty handlowe wraz z handlującymi tam ludźmi. Ci ludzie, w tym sensie, są częścią tej całości - niezbędnym elementem, aby ta całość funkcjonowała. Bez ludzi nie ma handlu, bez obiektów handlowych nie ma domu towarowego. Spójrzmy na jeszcze inny przykład - domy kultury są miejscami, do których przynależą rozmaite instytucje kulturowe, lokale kulturalno-rozrywkowe i tym podobne. Skoro mowa jest tu o instytucjach, to ponownie, mowa jest też o ludziach.

Z kolei „budując domy”, tworzymy budynki przeznaczone do zamieszkiwania. W ich potencjale kryje się już to, że ktoś będzie tam przynależał, podobnie jak w domach, które stoją puste. O domach mówi się też „mój dom”, „dom mojej rodziny”, „cudzy dom”. Do „mojego” domu przynależę ja i moja rodzina, do „cudzego" domu przynależą inni ludzie. Odwiedzając cudzy dom, możemy czasami uczynić go w pewnym sensie swoim, zwłaszcza jeżeli bywamy tam wyjątkowo często, a rodzina, którą odwiedzamy, staje się nam bardzo bliska. Możemy wtedy mówić o „domu przyjaciół” (zob. badanie Sixsmith).

Bywa też tak, że ktoś jest z jakiegoś domu, na przykład Katarzyna Radziwiłłowa $\mathrm{z}$ domu Sobieska. To określenie ma wskazywać, że ktoś przynależy do pewnego domu, rozumianego właśnie jako ród. „Katarzyna Radziwiłłowa z domu Sobieska” znaczy tyle, co „Katarzyna Radziwiłłowa jest częścią pewnej całości, którą jest ród Sobieskich".

A co zrobić z sytuacją, gdy mówimy o własnej ojczyźnie albo mieście, z którego pochodzimy, „to jest mój dom”? Oczywiście, jak się zdaje, mówimy tak, ponieważ czujemy, że przynależymy do tego miejsca. Pewne miasto jest moim domem, inne zdecydowanie już nie. „Zadomowić się” to w pewnym sensie „stać się przynależącym do jakiegoś miejsca”. Turysta zadomawia się na kempingu, pracownik zadomawia się $\mathrm{w}$ hotelu w czasie podróży służbowej, student zadomawia się w akademiku. Zadomawiający się rozstawiają swoje rzeczy, nawiązują kontakty ze współlokatorami, wybierają sobie łóżko, krzesło, biurko. Z biegiem czasu widać ślady tego, że ktoś tam już przynależy. 
Czasami też jest tak, że w jakimś miejscu przestajemy czuć się jak w domu. Tracimy poczucie przynależenia, stajemy się w pewnym sensie wykluczeni. Zdarza się to często w przypadku ofiar przemocy domowej. Określenie „dom” staje się pewnego rodzaju sentymentem lub marzeniem o miejscu, do którego naprawdę przynależymy. Przemoc w rodzinie niszczy stosunki międzyludzkie, burzy tę całość, do której przynależymy.

Mówimy również o zjawisku bezdomności, zwłaszcza wtedy, gdy chcemy podkreślić, że pewne osoby nie przynależą do żadnego miejsca. Czasami też mówi się, że domem bezdomnych jest ulica. $Z$ ich perspektywy to może być rzeczywiście dom, gdy znają wszystkie zakamarki okolicy, w której śpią, jedzą i żebrzą. Z perspektywy innych ludzi jednak, zwłaszcza tych, którzy mają własne mieszkania, te osoby rzeczywiście są bezdomne. Ważne jest jednak to, że kolejny raz pojawia się tutaj intuicja dotycząca przynależenia.

Często też mówi się o „normalnych domach”. Marzeniem niektórych bywa, aby mieć normalny dom, chociaż to określenie nie ma ostrego znaczenia. Czasami normalny dom to taki, który jest zamieszkiwany przez niepełną rodzinę, innym razem musi być to koniecznie rodzina składająca się z matki, ojca i dzieci, jeszcze innym razem ma być to miejsce, gdzie rodzice interesują się swoimi dziećmi, panują między nimi zdrowe relacje i każdy chce wracać do tego miejsca, ponieważ czuje, że do niego przynależy.

W języku istnieje mnogość użyć nazwy „dom”. Nie sposób ich wszystkich przeanalizować, pole do badań pozostaje otwarte i autor nie będzie rozstrzygał tutaj, czy rzeczywiście za każdym użyciem nazwy „dom” kryje się jakaś intuicja związana z przynależeniem. Trzeba jednak przyznać, że trudno znaleźć przykład użycia tej nazwy, w którym nie pojawia się jakaś intuicja związana z przynależeniem. Dlatego nie należy ignorować faktu, że często, gdy mówimy „dom”, to mówimy o jakiejś formie przynależenia.

Dlatego też - z dużą dozą ostrożności - stawiamy tu pewną hipotezę, która warta jest przemyślenia. Nazwa „dom” w pierwotnym znaczeniu dotyczyła schronienia, ogniska domowego, tego, gdzie jesteśmy my i rodzina. Skojarzenie takiego właśnie domu $\mathrm{z}$ przynależeniem ( $\mathrm{w}$ deskryptywnym rozumieniu) mogło sprawić, że określenie „dom” zaczęliśmy stosować w odniesieniu do innych znaczeń, jak na przykład ojczyzny i miasta. To mogłoby sugerować, że z jakiegoś właśnie powodu stan przynależenia do jakiegoś miejsca i wspólnoty, który może realizować się w domu, rozumianym w tym pierwotnym znaczeniu, jest dla nas 
tak ważny, że o innych miejscach, do których ktoś lub coś przynależy, mówimy właśnie „dom”.

\section{Przynależenie jako wartość nadrzędna domu}

Rozważania przeprowadzone w niniejszej pracy miały na celu zwrócenie uwagi na „przynależenie” jako możliwie nadrzędną wartość związaną z domem. Przynależenie, rozumiane jako pewna potrzeba wynikająca $z$ tego, że człowiek jest istotą społeczną, jest cenne dla człowieka, ponieważ potrzebujemy całości, w ramach których jesteśmy w stanie określić swoje miejsce. Bez przynależenia do jakiejś grupy społecznej czujemy się osamotnieni. W szczególności wydaje się, że to właśnie w domu chcemy czuć się tak, jakbyśmy gdzieś przynależeli. Rodzina, bliscy, nawet zwierzęta, z którymi mieszkamy, są tym, co - jak się zdaje - bardzo mocno cenimy sobie w warstwie społecznej „własnego” domu. Tak samo rodacy, znajomi i wspólnota kulturowa są całościami, które cenimy sobie w domu rozumianym jako ojczyzna albo miasto rodzinne. Z kolei pewna całość, którą jest budynek składający się na „własny” dom, pozwala nam realizować potrzebę spokoju w chaosie życia codziennego. Wracamy do domu, żeby odpocząć od zgiełku, ponieważ daje nam przestrzeń, do której przynależymy i w której możemy być sobą. W przypadku ojczyzny lub miasta, jeśli nazywamy je domem, fizyczne przynależenie może być rozumiane jako pewna znajomość okolicy, miasta i tak dalej.

W części o literaturze psychologicznej zwróciliśmy uwagę na pewną potrzebę realizacji poczucia przynależenia w domu, zarówno rozumianego jako „bycie częścią grupy”, jak i „bycie częścią jakiegoś miejsca fizycznego wraz z tworzącymi go przedmiotami”. Badania przeprowadzone przez Sixsmith pomogły nam zwrócić uwagę na to, jak ważne okazuje się być przynależenie, gdy mówimy lub marzymy o domu. W efekcie doszliśmy do wniosku, że niezbędnym elementem przynależenia jest poczucie swojskości. Zwróciliśmy również uwagę na to, że potrzeba przynależenia zawiera się w innych potrzebach.

W części o literaturze filozoficznej przywołaliśmy trzy prace. Heidegger zwrócił naszą uwagę na to, że w zasadzie zawsze gdzieś przynależymy. To pozwoliło nam odróżnić „przynależenie” rozumiane jako opis faktu od „przynależenia” rozumianego jako wartość. Rozważania Arendt z kolei pokazały, że dom jest miejscem, dzięki któremu człowiek może uczestniczyć w sprawach świata. Bez niego 
zaś nie ma swojego miejsca, dlatego dom chronimy za wszelką cenę. Zauważyliśmy również, że przynależenie w porównaniu do innych wartości, jak się zdaje, nie zmieniło swojej pozycji i od zawsze jest kluczowym elementem domu.

Wspomnieliśmy też o Wolniewiczu i in., którzy słusznie zwrócili uwagę na to, że dom jest miejscem, od którego oczekujemy, że będziemy cenieni jako wartość samoistna, bezwarunkowo. Jak wolno domniemać, szczególnie mocno przynależymy właśnie wtedy, gdy przynależymy bezwarunkowo, pozbawieni lęku przed utratą swojego miejsca w świecie. Na płaszczyźnie społecznej wyrazem tego jest bezwarunkowe przywiązanie bliskich do nas, natomiast na płaszczyźnie fizycznej na przykład to, że nikt nie może legalnie naruszyć granic naszej posiadłości. A zatem od domu oczekujemy, żeby realizowała się w nim wartość przynależenia lepiej niż w innych okolicznościach. Idealnie byłoby, gdyby była ona bezwarunkowa.

W ostatniej części wyprowadziliśmy pewną hipotezę, że w języku potocznym, gdy zazwyczaj używamy nazwy „dom”, opisujemy jakąś formę przynależenia. Przeanalizowaliśmy kilka przykładów, zostawiając przy tym otwarte drzwi do dalszych badań. Przypuszczalnie jest tak, że ze względu na to, jak ważne dla nas jest przynależenie, gdy myślimy o domu, tych czterech kątach wraz z nadbudową duchową, używamy tego określenia również w innych kontekstach, gdy mamy na myśli jakąś formę „silnego” przynależenia. Chodziło nam tutaj o podkreślenie wagi, którą przywiązujemy do przynależenia, gdy myślimy o domu.

Nie powiemy oczywiście, że od każdego miejsca, do którego przynależymy, oczekujemy, żeby było domem, ale - jak się zdaje - od każdego miejsca, które jest domem, oczekujemy przede wszystkim, że sprawi ono, iż poczujemy się tak, jakbyśmy do czegoś przynależeli. Nie próbowaliśmy tutaj również pokazać, że przynależenie jest jedyną wartością nadrzędną domu albo najważniejszą spośród nich. Istnieją jednak silne przesłanki, aby domniemać, że mieści się ono wśród tych wartości, które rzeczywiście należy uznać za najcenniejsze, czyli takie, które chcielibyśmy realizować i chronić. Wracając więc do pytania postawionego na początku artykułu, być może jest tak, że powiedzenie „wszędzie dobrze, ale w domu najlepiej" wyraża pewną tęsknotę, aby wrócić tam, gdzie czujemy, że przynależymy. 


\section{Bibliografia}

Arendt H., Kondycja ludzka, tłum. A. Łagodzka, Fundacja Aletheia, Warszawa 2000.

Grzegorczykowa R., Zarys słowotwórstwa polskiego. Słowotwórstwo opisowe, Państwowe Wydawnictwo Naukowe, Warszawa 1979.

Heidegger M., Budować, mieszkać, myśleć, tłum. K. Michalski, „Teksty: teoria literatury, krytyka, interpretacja”, nr 6(18), s. 137-152.

Israel T., Some Place Like Home: Using Design Psychology to Create Ideal Places, Wiley, Hoboken, N.J. 2003.

Maslow A., The farther reaches of human nature, Viking Press, New York 1971.

Sixsmith J., The meaning of home: an exploratory study of environmental experience, „Journal of Environmental Psychology” 1986, Vol. 6, No. 4, s. 281-298.

Słownik Języka Polskiego, red. W. Doroszewski, Wydawnictwo Naukowe PWN, Warszawa 1966.

Słownik Jezzkka Polskiego PWN, URL: https://sjp.pwn.pl.

Schrade U., Wolniewicz B., Zubelewicz J., Dom jako wartość duchowa, „Znak” 1996, nr 4(491), s. 90-108.

Tuan Yi-Fu, Place: An Experiential Perspective, „Geographical Review” 1975, Vol. 65, No. 2, s. 151-165.

\section{Streszczenie}

W tym artykule autor przygląda się przynależeniu jako potencjalnie jednej z najważniejszych wartości domu. Omawia wybrane koncepcje filozoficzne, badania psychologiczne i intuicje przejawiające się w języku potocznym, po to aby znaleźć odpowiedź na pytanie, czy nie jest tak, że przynależenie jest jedną z najważniejszych wartości związanych z pojęciem domu.

Słowa kluczowe: wartości związane z domem, wartości domu, przynależenie, przynależność, Heidegger, Sixsmith, Arendt, znaczenie domu 


\section{Summary}

\section{On the Belonging as the Superior Value of Home}

This paper takes a look at belonging as potentially one of the most important values of home. The author discusses selected philosophical concepts, psychological research and intuitions manifested in everyday language to find an answer to the question whether belonging is indeed one of the most important values associated with the concept of home.

Key words: values associated with home, values of home, belonging, Heidegger, Sixsmith, Arendt, meaning of home 